\title{
Niebuhr, Evil, and the Holocaust
}

\author{
C. Fred Alford \\ Department of Government and Politics, University of Maryland, College Park, USA \\ Email: calford@umd.edu
}

Received October 21 ${ }^{\text {st }}$, 2013; revised December $2^{\text {nd }}, 2013$; accepted December 20 ${ }^{\text {th }}, 2013$

Copyright (c) 2014 C. Fred Alford. This is an open access article distributed under the Creative Commons Attribution License, which permits unrestricted use, distribution, and reproduction in any medium, provided the original work is properly cited. In accordance of the Creative Commons Attribution License all Copyrights (C) 2014 are reserved for SCIRP and the owner of the intellectual property C. Fred Alford. All Copyright (C) 2014 are guarded by law and by SCIRP as a guardian.

\begin{abstract}
Reinhold Niebuhr could not think thoroughly about the Holocaust. This may surprise some, for Niebuhr is generally known as the hard-headed realist who understood sin and evil to be real and active in the world. Niebuhr could not think thoroughly about the Holocaust because he could not think thoroughly about the emergence of a new type of evil. If Germans took pleasure in the destruction of Jews for its own sake, then the meaning of history is itself put at risk, at least for those who would learn from Niebuhr. For all his realism about sin and evil, Niebuhr cannot imagine a world in which the mysterious meaning of history will not be revealed at the end of days. For many who survived the Holocau ${ }^{*}$ st, Auschwitz was the end of days. This does not make their experience definitive for the rest of us. It does mean that evil, when pursued for ends that are fundamentally meaningless, threatens both faith and confidence in the meaning of history. In thinking about the Holocaust, this essay draws not only on Hannah Arendt, but also on my own research in the Fortunoff Video Archive for Holocaust Testimony at Yale University.
\end{abstract}

Keywords: Niebuhr; Holocaust; Evil; Arendt

\section{Introduction}

In 2007, New York Times columnist David Brooks interviewed then-senator Barak Obama about Reinhold Niebuhr. "What do you take away from him?” asked Brooks. Obama replied. "I take away $\cdots$ the compelling idea that there's serious evil in the world $\cdots$ But we shouldn't use that as an excuse for cynicism and inaction. I take away $\cdots$ the sense we have to make these efforts knowing they are hard, and not swinging from naïve idealism to bitter realism.” (Brooks, 2007) Subsequently, many noticed the presence of Niebuhrian themes in President Obama's Nobel Prize acceptance speech (Lemert, 2011, p. 213). Niebuhr has been on something of a roll recently, and yet I argue that about an aspect of evil, The Holocaust, he was insufficiently serious. Or rather, about this expression of evil, he could not come to terms.

It is not because Niebuhr lacked compassion, and certainly not because he failed to understand the National Socialist threat to civilization. He understood that better than most of his generation. Niebuhr could not think thoroughly about the Holocaust because he could not think thoroughly about the emergence of a new type of evil.

This may surprise some, for Niebuhr is generally known as the hard-headed realist for whom original sin is the only "empirically verifiable doctrine of the Christian faith." (Niebuhr, 1965, p. 24) Niebuhr also understood evil to be real and active in the world. It is a leading theme of his Gifford Lectures, The Nature and Destiny of Man.

Initially opposed to United States involvement in World War Two, his pre-war trips to Germany in the company of Paul Tillich convinced him otherwise. In 1933, Niebuhr wrote that evi- dence was mounting that Nazi Germany’s “effort to extirpate the Jews in Germany is proceeding with unexampled and primitive ferocity.” (Niebuhr, 1933, p. 1014) Ignorant of the real situation, the German people seemed to largely believe that the alleged atrocities were little more than Jewish propaganda. Good Germans, in whom both he and Tillich believed, were in a state of denial as to what was happening in their own country (Rice, 2013, pp. 20, 33).

Niebuhr was on the right side, speaking out against anti-Semitism in Germany, leading efforts to find homes and work for refugee Jewish intellectuals. Discovering that his sponsorship of one refugee was the reason why his visa had been held up, Niebuhr asked his friend Felix Frankfurter to intervene. It turned out that Niebuhr was on a list of communist sympathizers thanks to his associations with leftist publications from the previous decade. The Supreme Court Justice had enough political clout to get Niebuhr's name removed from the Red List, and the visa was secured (Rice, 2013, pp. 208, 209).

During the war, Niebuhr and Tillich, a gentile refugee from Nazi persecution, spent most of their time preparing for the postwar era, when the Germans could once again be integrated into the community of nations. After the war, Niebuhr spoke out in favor of the claim of the Jewish people for a homeland. Assimilation, he grasped, can mean the death of a people. There is, he said,

A curious, partly unconscious, cultural imperialism in theories of toleration that looks forward to a complete destruction of all racial distinction. The majority group expects to devour the minority group by way of assimilation. This is a painless death, but it is death nevertheless. (Nie- 
buhr, 1957).

Abraham Heschel gave the lead eulogy at Niebuhr's June 1971 memorial service, stating simply that "He appeared among us as a figure out of the Hebrew Bible $\cdots$ Niebuhr's life was a song in the form of deeds.” (Crouter, 2010, p. 2) Aside from the fact that Niebuhr and Heschel had become close friends in later years, it was especially fitting that Heschel give the eulogy. Niebuhr was never especially interested in the intricacies of Christian doctrine, such as the Trinity. On the contrary, quotations from the Hebrew Bible appear almost as often as from the Greek Testament. In particular, Niebuhr rejected supersessionism before its rejection became acceptable among many Christians. Supersessionism is the view that the New Covenant of Christ replaces the Mosaic or Old Covenant. Supersessionism is multifaceted. Suffice to say it has been the doctrine of most branches of the Christian Church, even as it has less of a hold among many contemporary Christians (Johnson, 2003).

Niebuhr's failure to grasp the evil of the Holocaust was no moral failure on Niebuhr's part. It reflected no failure to understand or respect Judaism. The problem was not that Niebuhr neglected the Holocaust because it was primarily a Jewish catastrophe. The problem is that the Holocaust was too evil. Not too evil for Jews to suffer, or Christians to contemplate. Too evil to know.

Niebuhr wrote hundreds of occasional pieces, reactions to current events. Christianity and Crisis was founded by Niebuhr in 1941 to encourage American intervention in the European war against Nazism, and in it he published dozens of pieces, as well as hundreds elsewhere. In 1936, he went to Germany with Tillich for a second time. This time he brought the Church's protest against the concentration camps and the persecution of the Jews to Hitler's finance minister, who read it to Hitler in Niebuhr's presence (Rice, 2013, p. 23). Hitler walked out. Niebuhr's distance was not geographical or temporal. It was conceptual.

The too easy answer as to why Niebuhr never confronted the evil of the Holocaust is that he was influenced by Augustine, and for Augustine evil does not exist; it is an absence or privation in God's good world. Several things are wrong with this answer. First, to attribute Niebuhr's failure to confront the evil of the Holocaust to the Augustinian influence on his thinking is no explanation at all. It simply pushes the problem back on Augustine. Second, the Augustinian influence on Niebuhr had to do with Augustine's view of evil as arising from self-love (Niebuhr, 1986). Third, for Niebuhr evil is in many respects the opposite of privation. Evil is an attempt to take the place of God (Niebuhr, 1996, vol. 1, pp. 150, 168, 169). This turns out to be a fairly fruitful perspective from which to view the evil of the Holocaust; certainly it is not a barrier. The Augustinian influence on Niebuhr, which came late and is readily exaggerated, poses no problem to his understanding of evil.

\section{The Evil of the Holocaust: Niebuhr and Arendt}

Modern tyrannies, said Niebuhr, are not the end product of a long history of tyranny, one in which ancient evils have been slowly perfected. Instead, they are the "characteristic corruptions of a mature civilization in which technical instruments have become more effective tools of tyrannical purpose." The purpose, Niebuhr understands, is not only the destruction of life, but the worship of the power of the regime itself. Idolatry is the telos of sin (Niebuhr, 1996, vol. 2, pp. 318, 319).

Compare Niebuhr's analysis with Hannah Arendt's understanding of modern tyranny in The Origins of Totalitarianism. Concentration camps, says Arendt, are the realization of the totalitarian ideal. They are meant not merely to exterminate and degrade human beings, but serve as "the ghastly experiment of eliminating, under scientifically controlled conditions, spontaneity itself as an expression of human behavior and of transforming the human personality into a mere thing..." (Arendt, 1976, p. 438) The result, or at least the goal, is that all that is expressive of humanity, above all plurality and natality, disappear. With the term "natality," Arendt refers to the ability to give birth to something new, and so defeat the forces of entropy that would unwind the world. This new thing could be a child, an artistic creation, or an act of self-giving love.

There are, Arendt continues,

No parallels to life in the concentration camps. Its horror can never be fully embraced by the imagination for the very reason that it stands outside of life and death. It can never be fully reported for the very reason that the survivor returns to the world of the living, which makes it impossible to believe fully in his own past experience. (1976, p. 444).

This is supported in interviews with concentration camp survivors, many of whom make this same point. As Eva L. puts it, "I can't believe it happened to me $\cdots$ How can they believe if I can't believe (T-71) ${ }^{1}$ ?” In many respects disbelief is the primary experience of the camps among those who survived, an experience that does not diminish with age. Or as Abe L. puts it,

I thought that when the years go by, the Holocaust would go further away.' I dream about it. I can't get something like that out of my system. All gone now, especially the children. You can't get that out of your mind. The hole in your heart gets bigger. The Holocaust is getting closer not farther (T-1394).

Survivors cannot report their experience to others, not because others are insensitive (though they often are), but because they can hardly report their experiences to themselves.

I made a videotape for my daughter. She said "mommy, you must be so sad." But when I see it, it's like it happened to another person $\cdots$ At moments you get mushy, but at moments you think you're telling someone else's story. (Sonia, T-1681).

Arendt (1976, pp. 453, 454) draws a distinction between the early spontaneous bestiality of the camps, carried out for the most part by the SA, "as a concession of the regime to its criminal and abnormal elements," and the latter, when the SS took over the camps, cold and systematic destruction of human bodies, "calculated to destroy human dignity; death was avoided or postponed indefinitely ${ }^{2}$." While the distinction is worth not-

${ }^{1}$ Quotations from survivors, unless otherwise noted, are all taken from my research in the Fortunoff Video Archive for Holocaust Testimonies at Yale University. This is an ongoing research project begun in 2007. Some of the results are published in Alford (2009), more in Alford (2013). While the testimonies are not anonymous, the Archives prefers this method of citation first name followed by (T-[accession number]). I have spent hundreds of hours viewing over two hundred testimonies.

${ }^{2}$ The SA was the Sturmabteilung, aka Brownshirts, original Hitler supporters from unemployed soldiers, bar-room brawlers, and working classes, as opposed to generally middle-class SS men. The SA were politically marginalized from 1934, though some members served under the SS. 
ing, it is important to remember that cold and calculating cruelty is the mark of sadism. Not the instrumental killer, not the enraged killer, but the sadist turns murder, in this case mass murder, into a technology.

Max Horkheimer and Theodor Adorno (2002) understood this well in Dialectic of Enlightenment. Rage at a nature too sparse to be dominated is transformed into the rationalized domination of nature. In the case of the Holocaust, Jews, gypsies, gays, and others exemplify undominated nature, aspects of nature which are impure, and so must be destroyed. The dialectic of Enlightenment concerns the way in which the most modern means of science and technology come to serve the most primitive superstitions, such as the fear of impurity (Douglas, 2002).

It is in The Origins of Totalitarianism that Arendt (1976, pp. $443,458,459)$ develops the concept of "radical evil," a concept she will later reject ${ }^{3}$. What exactly she means by the term radical evil is unclear. Perhaps her clearest explanation is that the motives of the evil doers are no longer humanly comprehensible. Their absolute evil

could no longer be understood and explained by the evil motives of self-interest, greed, covetousness, resentment, lust for power, and cowardice $\cdots$ Just as the victims in the death factories or the holes of oblivion are no longer "human" in the eyes of their executioners, so this newest species of criminals is beyond the pale even of solidarity in human sinfulness (1976, p. 459).

The most salient aspect of radical evil for Arendt seems to be its incommunicability. Because there are no parallels to life in the concentration camps, its horror can never be fully embraced by the imagination for the very reason that it stands outside of life and death. It can never be fully reported for the very reason that the survivor returns to the world of the living, which makes it impossible for him to believe fully in his own past experience (Arendt, 1976, p. 444).

We have seen this is partially true. However, one might well argue that survivors who struggle with their ability to believe their own experiences, and are able and willing to convey this struggle to others have already begun to reclaim their experience. But Arendt is biased. She does not want the story to be told. "The more authentic they are," the more accounts of sufferings "transform men into 'uncomplaining animals'," the less these reports inspire the passions of outrage and sympathy which inspire men to seek justice "Only the fearful imagination of those" who have been aroused but not smitten in their own flesh and "who are consequently free from the bestial, desperate terror'. can afford to keep thinking about horrors." (Arendt, 1976, pp. 439, 441) Was Arendt referring to herself, and the intellectual distance she achieved as a Jewish refugee intellectual? Do we really need such distance? Perhaps the passage of time has made some things easier. Let us try to get a little closer.

\section{Radical Evil}

Arendt defines radical evil as evil that is inexplicable in

${ }^{3}$ Later, after covering the trial of Adolf Eichmann for The New Yorker magazine, Arendt would give up her belief in radical evil, saying "it is indeed my opinion now that evil is never 'radical', that it is only extreme." The passage is from an "acrimonious exchange" between Arendt and Gershom Scholem (Elshtain, 1995, p. 76). In her later view, evil is not radical because it has no depth; that is its banality. In fact, that view does not seem so far from the definition of radical evil offered here: that evil lacks the depth of motivation so as to make it humanly comprehensible. terms of human motives. But there is one motive she omits. People commit radical evil because they like to hurt other people. In particular, some people like to hurt the innocent and good because they are innocent and good. Though he originated the term radical evil (radikalen Bösen), not even Kant could abide this possibility, for this would mean that some men and women would seek destruction for its own sake. That would mean that some humans possessed "a thoroughly evil will $\cdots$ and thus the subject would be made a devilish being. Neither of these designations is applicable to man (Kant, 1960, pp. 3032)."

About her imprisonment at Bergen-Belsen, Fela Nichtauser refers to the German SS guard Irma Grese who forced women prisoners to stand to attention in all kinds of winter weather from 08:00 until 11:00 for the Zahlappel (the daily count), without anything covering their heads in the snow and rain. At $11 \mathrm{am}$ or after, Grese would arrive.

And when she would notice that some girl would have that little piece of blanket on her head she would approach her immediately with a smile and would tear down that piece of blanket with the person together. She would call her dog. The dog would jump at the girl and gnash its teeth as if he was going to bite. Irma Grese did not permit him to bite. She just wanted to horrify us. She wanted to cause anguish and terror, and that was much worse. So she would throw down this blanket together with the person and kick her and beat her with her whip.

Ms. Nichthauser concludes this portion of her testimony by saying, "I can just tell you that the block seniors were no bet-

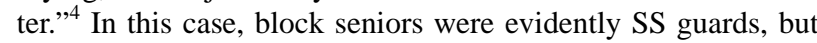
in most cases they were political or ordinary prisoners in charge of a particular barrack.

Irma Grese operated within the SS bureaucracy. Other guards were perhaps not as cruel, but Grese's cruelty faced no resistance at Bergen-Belsen. She served Bergen-Belsen’s purpose; her brutality was both instrumental and functional for the institution.

Consider, in this regard, Daniel Goldhagen's Hitler's Willing Executioners: Ordinary Germans and the Holocaust, a somber reinterpretation of the Holocaust in terms of the eagerness of ordinary Germans to collaborate in the destruction of the Jews. In the middle of this long (over 600 pages), sometimes mindnumbing account of the organization of hatred and death, one is surprised to find Goldhagen (1996) drifting off into sexual fantasy, imagining a post-coital dialogue between prison guards.

The Germans made love in barracks next to enormous privation and incessant cruelty. What did they talk about when their heads rested on their pillows, when they were smoking their cigarettes in those relaxing moments after their physical needs had been met? Did one relate to another accounts of a particularly amusing beating that she or he had administered or observed, of the rush of power that engulfed her when the righteous adrenaline of Jew-beating caused her body to pulse with energy (p. 339)?

What is it about the Holocaust that leads even the sober his-

${ }^{4}$ The testimony of Fela Nichthauser is from the research of David Boder, the first person to audiotape the testimony of survivors in 1946. See Alford (2009). 
torian to fantasize about the sexual lives of the prison camp guards?

Presuming these fictional guards were not ranking officers (and perhaps even if they were), they probably went on to live normal lives in post-war Germany, raising children, never thinking, never having to think, and about what went on in the other "barracks" next door. Certainly tens of thousands of real guards did. Incomprehension is another part of the answer: that humans could take such pleasure in inflicting pain. For Goldhagen addresses that issue, a key reason his book was so successful among the public, even as it failed to convince many scholars (Zank, 1998).

Germans tormented, degraded, and killed Jews because they wanted to, because they liked to do it, because it made them feel powerful, and good, and clean, and righteous to do so. To have said as much is the distasteful secret behind the vast commercial success of Hiltler's Willing Executioners: over onehalf million books sold in the Americas and Europe. And yet the large number of books sold suggests that this secret was hardly a secret at all.

What is so hard to imagine is what we already know. Knowledge as disaster, Maurice Blanchot (1995, p. ix) calls it. The problem isn't learning something new; the problem is accepting what we know about ourselves and humanity. Something terribly simple, and simply terrible. Under certain circumstances, most people (not everyone) when given unlimited power over others who have already been degraded, devalued, and dehumanized will use this power to degrade, dehumanize, and ultimately destroy these others. Furthermore, there is no larger metaphysical reason, despite recent attempts to transform the language of the "Other" into a philosophical ontology. People don't like to hurt "the Other." They like to hurt particular other people in particular circumstances, especially when they are invited to do so. This involves two steps: first, permission by those in authority, and second the degradation of the victims. The fact that the victims are ruined by those who will then use their degradation as an excuse to humiliate and destroy them makes no difference. The only logic at work here is psychologic.

To a person of ordinary imagination, historical literacy, and psychological insight, the Holocaust as an act by which a large group of humans found pleasure in tormenting, degrading, and finally killing another group of humans is quite imaginable. This statement applies even to that most terrible act, to which Heinrich Himmler and his tens of thousands of followers came shockingly close, "that this people should disappear from the earth."

Saul Friedlander (1993, pp. 109-111) refers to the "Rausch," the intoxication of destruction, which seems to have seized Himmler and other Nazi leaders as the goal of destroying an entire people came within their grasp. Is this unimaginable? Why should it be? Pleasure in destruction, in destroying the innocent and good because it is innocent and good, has a long history. "Evil be thou my Good," says Milton's Satan. (Paradise Lost iv, 105-110) When William Blake said that Satan gets all the best lines in Paradise Lost he was not kidding. Satan is often an attractive figure, just as evil may be attractive, and that should be cause for deep concern.

Hope, Enlightenment faith in reason, progress, belief in a particular human vision of God: all this and more is transgressed by the Holocaust. But to claim, as some such as Berel Lang have, that the destruction of these human ideals is the inversion of the sublime, reality shattering the bounds of the imagination for evil, says more about the narrowness of an imagination than anything else (Lang, 2000, pp. 56, 57). Or rather, about the blinders we put on our self-knowledge, individually and collectively - that is, as historians of our species.

But what we know, and imagine now about evil is vastly different than what we knew, or could imagine, in 1935, is it not? Of course, or there would be nothing new to learn, no history to learn from. My claim is simply that barbarism, the lust to destroy, and pleasure in mass murder did not begin or end then. To be sure, the Holocaust did bring something new to our knowledge of evil: that it is subject to an absurd rationalization, captured far better by Raul Hilberg's account of the German railways (Reichsbahn) schedule of fares to bring "passengers" to the concentration camps than any sado-sexual fantasy Goldhagen could dream up.

The basic charge was the third-class fare: 4 pfennig per track kilometer. Children under 10 were transported for half this amount; those under four went free $\cdots$ For the deportees one-way fare was payable; for the guards a round-trip ticket had to be purchased (Hillberg, 1985, p. 411).

With this rationalization of destruction, the Holocaust did bring something new into the world, similar to the banality of evil that Arendt writes of, but which is better captured by the term absurdity of evil. The absurdity of evil is akin to the world of Franz Kafka, in which the rationality of everyday life goes on in heightened form even as the goals it serves become more obscure, evil, and obscene. Perhaps the obscurity of the goals, the mark of absurdity, is itself a defense against knowledge of the evil seemingly rational men and women are pursuing, but about this I am not sure. I am sure that this is no new idea, but a version of Horkheimer and Adorno's (2002) dialectic of Enlightenment, in which extreme rationalization is bound to the return of ever more mythic goals of blut und boden, purity, and human sacrifice.

When asked for an explanation of the Holocaust, generally we want more: that it makes sense, which often means that the end was present in the beginning if only we could have seen it. This seems to be what Primo Levi (2001, p. 232) means when concludes from the impossibility of a complete explanation of the Holocaust that no explanation is possible. One consequence is that we are led further and further from the one explanation that really works in these matters. An explanation that is not really an explanation at all, but a redescription of what happened in terms of the simplest of human motives. For various simple and complex reasons we need not, and generally do not understand, people do what they want to do. Germans and others tormented and killed Jews, gypsies, gays and others because they wanted to, because it gave them pleasure to do so. Is this not transgression enough?

The Holocaust is not a universal sign or metaphor, but an act of destruction initiated by one exclusive group against another group, based upon the first group's will-to-power to deny not just identity but existence to another group. The Holocaust is absurd because some people have rendered the human world so morally incomprehensible that it becomes almost impossible to see one's way out, even years after the event. We should not underestimate the destructive power of the absurd upon the human psyche. Not just upon the Holocaust's victims, but on 
those who would try to make sense of it.

\section{Niebuhr, Sin, Evil and the Meaning of History}

Is Niebuhr's account of sin and evil commensurate with the preceding account of the Holocaust? The preceding account begins with Arendt's explication of radical evil, going on to argue that Germans tormented, tortured, and killed Jews because they wanted to, because it gave them pleasure. There is a not so subtle operational definition of evil at work in this second account. Evil is pleasure in inflicting pain and destruction upon innocent life for its own sake, because the ability to do so itself brings gratification, rooted in the power to play God (or in this case Satan) by desecrating innocence and destroying goodness. Add to this a lack of remorse, and one has a working definition of evil for our times. Perhaps not a comprehensive definition. There must be other expressions of evil. But this seems a good start.

The question of whether Niebuhr's account of sin and evil is commensurate to our working definition of evil has no simple answer. Niebuhr is more interested in communal than individual sin. That is a good start for the evil represented by the Holocaust. Niebuhr is interested in the self-worship of the community, or its false gods, be they reason, science, or the Nazi Party. "Communal idolatry" is the most common sin of our time, certainly the most damaging in scale and intensity. For Niebuhr, sin, and with it idolatry, is an anxious attempt to hide our finitude, to make ourselves the center of life, and so take the place of God. We are all vulnerable to contingency, what the ancient Greeks called tyche. Each of us can imagine an infinity of horrors that might befall the self. And so humans seek by an act of will, what Niebuhr (1944, p. 139) calls the will-to-power, to overreach the limits of human creatureliness. Since most people lack the ability to do this on their own, they join communities of wild self-assertion (verwilderte Selbstbehauptung), as they have been called (Habermas, 2008, p. 198).

Sin, communal idolatry, and the will-to-power. Taken to an extreme these are enough to explain the Holocaust. Are they enough to understand it? Original sin is understood by Niebuhr not in the Biblical sense, the legacy of Adam's concupiscence. Original sin stems from the subject's fear at being alone and vulnerable in the world, leading him or her to worship the gods of the community, indeed the god that is the community. When this community worships the will-to-power, it becomes a predator among nations, and a marauder among the marginal within the community itself.

Idolatry is such a strong human tendency because we are all meaning-seeking and afraid. The only alternative is a true humility, based on the knowledge that there exists a divine judgment superior to our own. Though he has no where stated that he was influenced by Niebuhr, Václav Havel (1995) understood the danger of communal idolatry in a way that Niebuhr would have appreciated.

The relativization of all moral norms, the crisis of authority, the reduction of life to the pursuit of immediate material gain without regard for its general consequences- the very things Western democracy is most criticized for-do not originate in democracy but in that which modern man has lost: his transcendental anchor, and along with it the only genuine source of his responsibility and self-respect $\cdots$ Given its fatal incorrigibility, humanity probably will have to go through many more Rwandas and Cher- nobyls before it understands how unbelievably shortsighted a human being can be who has forgotten that he is not God (pp. 49-50).

It is not uncommon among those who admire Niebuhr to regard his theology as though it was an afterthought. Hans Morgenthau and George Kennan represent this tendency among international relations realists, but the philosopher Sidney Hook (1943, p. 13) put it most plainly when he said "not one of the positions that Niebuhr takes on the momentous issues of social and political life is dependent on his theology." Hook is correct in a strictly logical sense. None of the positions Niebuhr took on the positions of the day (1930's-mid-1960's) would be incoherent absent a belief in God. But almost all that is subtle and interesting about Niebuhr depends on this belief.

Particularly poignant is Niebuhr's view that God is not victorious in history, for evil is not defeated. Rather than imposing His goodness upon the world, God suffers the injustices of the powerful. To be sure, Niebuhr holds that God would not allow evil to completely triumph over the face of this earth. But human history is marked by the "scandal of the cross", the willing defeat of God in this world.

The perfect love which [Christ's] life and death exemplify is defeated, rather than triumphant, in the actual course of history. Thus, according to the Christian belief, history remains morally ambiguous to the end $\cdots$ Suffering innocence, which reveals the problem of moral ambiguity in history, becomes in the Christian faith the answer to the problem at the point when it is seen as the revelation of a divine suffering. (Niebuhr, 1949, p. 135)

In the meantime, all we know, all we can know, is that there is a decisive difference between good and bad, right and wrong. Historical outcomes are not merely relative or subjective. History doesn’t “just happen,” as Richard Rorty (1989, pp. 184, 185) would have it. Consequently, we can know that it is worthwhile fighting for the good, and we need not become overly discouraged when we lose, as we often will. Worthwhile means that fighting for the good is a meaningful (and not absurd) activity. Neither is it simply an existential choice, receiving its value because I have chosen it. Fighting for the good can be measured by, and receives its value from, a standard of infinite value. We have been given a glimpse of this good and its standard, even if in practice this glimpse is indistinct. The good's basic principles were laid down in the Hebrew and Greek Testaments. The scandal of the cross reflects a determination to be utterly realistic about the prevalence of evil in the world, while remaining committed to the belief that history is meaningful because it has been given meaning by the traces of God's presence.

Nonetheless, Niebuhr has a problem. The knowledge of God in history is not known through the study of history. It is grasped inwardly, by repentance and "the shattering of the self," placing one's trust in divine power and mercy. Niebuhr is referring to the type of knowledge often characterized in terms of revelation or faith. Gilkey (2001, pp. 193-104) uses the term "existential," in order to stress the similarity between the knowledge Niebuhr assumes and the knowledge Søren Kierkegaard writes about. How then can Niebuhr make this knowledge (if that is what it is) relevant to the fate of human collectivities, and hence to history, which is clearly what Niebuhr wants to do? Niebuhr writes about "structures of common grace 
in history," but this is not very convincing. What he seems to mean is moments when the interests of the ruling class and the community come together, as in the United States with civil rights, or South Africa when apartheid was ended without a bloodbath. This seems less than a fully satisfactory explanation.

\section{Conclusion}

Is it possible that the Holocaust represents a new form of evil, one that mocks the meaning of history? One might argue that this is strictly a religious question, one that may divide Christians and Jews. But even if this is a question of theological difference (as well as theological distance), it is not only a theological difference. Not, if the Holocaust has brought a new evil into our world.

For Niebuhr, the Holocaust is not unique, but an exemplary corruption "of a mature civilization in which technical instruments have become more effective tools of tyrannical purpose." The purpose is not only the destruction of life, but the worship of the power of the regime itself (Niebuhr, 1996, vol. 2, pp. 318, 319). What if this were not simply the case? What if the Holocaust represented a break even with the other industrially organized horrors of the twentieth-century: two world wars, Hiroshima, Stalin, Mao Zedong, a woefully incomplete list. Why would the Holocaust represent a break?

Because National Socialism worshiped not only itself, and not only its power over life and death. National Socialism created a world of industrialized and organized sadism, whose goal was to rationalize pleasure in the torment, torture, and degradation of the innocent before they are destroyed. Arendt grasped this; it is what she called radical evil, before retreating from the concept. Daniel Goldhagen grasped it, and so presumably did tens of thousands of his readers, even if more sober historians did not. Saul Friedlander grasped this point with his concept of the Rausch, the intoxication that must have seized the organizers of the Holocaust when the ultimate transgression, the elimination of a people, a genos, seemed within their grasp.

One imagines that sadism, pleasure in the degradation and destruction of the innocent, must be carried out by perverted individuals if it is to give them any satisfaction. This turns out not to be true. People at some distance, either bureaucratic distance, or the distance of people who only have a hazy understanding of what is going on, can experience great satisfaction, perhaps even greater satisfaction, because they can know and not know at the same time. They can know, and yet not get too close, even to their own knowledge. Niebuhr wrote that in the years leading up to the Holocaust, good Germans were in a state of denial about what was happening in their own country. A state of denial stands close to that state of knowing and not knowing, and perhaps there is satisfaction in resting there: the satisfaction of vicariously participating in the desecration of the Jews while not letting oneself know that this is what one is doing.

The Holocaust was the conjunction of evil and absurdity. Evil in all the ways is described. Absurdity in the rationalization to which it was subjected, so that evil becomes one more thing to be administered by the state and its institutions, as exemplified by the Reichsbahn schedule of fares to bring "passengers" to the concentration camps. This combination of evil and absurdity does not contradict an interpretation of history in which God stands at the end point, suffering with us along the way. Nothing could contradict this interpretation, for it does not depend on actual history for its validity. Nevertheless, there is something about the conjunction of evil and absurdity that mocks the meaning of history. Primo Levi tells the story of a prison guard who snatched an icicle out of his hand just as he was about to suck on it to relieve his terrible thirst. "Warum?" asked Levi. "Hier ist kein warum" answered the guard. Here there is no why, no reason, no point in asking because there is no answer (Levi, 1996, p. 29). This occurred during the first few days of Levi's year-long imprisonment in Auschwitz. The answer never changed.

For Niebuhr, history is fundamentally mysterious. We do not know its meaning, but we know that it has a meaning, a meaning expressed most richly in Biblical myth. There are other myths. One of the most well-known contemporary myths is The Myth of Sisyphus, by Albert Camus, in which there is no meaning but that which man self-consciously creates for himself. Or as Gilkey (2001) puts it, for Niebuhr

"the problem of history" is the question of the meaningfulness of history $\cdots$ However obscure that meaning may be $\cdots$ [Niebuhr] never drew the conclusion from that obscurity that there might in fact be no meaning to history at all $\cdots$ For examples of this latter view, see the works of Albert Camus, especially The Myth of Sisyphus (p. 146; cf. p. 62).

My claim is that the Holocaust represents a new type of evil. An evil that was not primarily instrumental, but whose goal was the infliction of torment, torture and degradation for its own sake. Death was only the last station on this journey. An evil which never lost these qualities, even as it became more and more bureaucratized and rationalized. It is this combination that renders the evil of the Holocaust absurd, as Horkheimer and Adorno recognized. They were referring to the conjunction of primitive superstition and modern rational methods of destruction. I refer to primitive satisfaction in desecration of the good, disguised and given free reign by the ideology and rationalization of Nazi propaganda and bureaucratic practice. Arendt (1965, p. 150) seems to be getting at a similar point when she said "evil in the Third Reich had lost the quality by which most people recognize it - the quality of temptation."

This doesn't mean that Niebuhr is wrong about the mysterious meaning of history. He could not be wrong, for his is a theological claim, not an empirical one. The absurdity of evil means that it becomes more difficult to find meaning in the meaning of history, for absurdity is not mysterious; it is simply absurd. The mark of absurdity is that it mocks meaning, as Niebuhr and Gilkey understand. To be sure, one can continue to hold to the view that the meaning of history is mysterious. Only at some point, does not the mystery itself become absurd, pointless? At some point one wants not mystery, and not even clarity, but simply for the insanity to stop. Those with the power and will to make it stop become, at least for a time, the source of meaning. This is dangerous business, dangerous thinking, for those who stop the insanity will soon seek their turn to become gods, and one hopes more charitable ones. By then the absurdity of evil will have done its work, leaving a hole in history too big for any meaning to fill. This includes any theory of postponed meaning: that the mysterious meaning of history will become clear only at the end of days. For have those who experienced the Holocaust not experienced that too? A perverted version, to be sure, Auschwitz as the end of all days. But that's 
what mockery is.

For all his realism about sin and evil, Niebuhr never got close enough to the Holocaust to let himself be touched by this experience, the desecration and degradation that mock all meaning. Niebuhr was too much of an activist to be touched in this way. This is not necessarily a criticism. The world requires all types. But it sets a limit to Niebuhr's understanding.

\section{REFERENCES}

Alford, C. F. (2009). After the holocaust: The book of job, Primo Levi, and the path to affliction. New York: Cambridge University Press. http://dx.doi.org/10.1017/CBO9780511800412

Alford, C. F. (2009). What if the Holocaust had no name? Holocaust studies. A Journal of Culture and History, 15, 71-94.

Alford, C. F. (2013). Trauma and forgiveness: Consequences and communities. New York: Cambridge University Press. http://dx.doi.org/10.1017/CBO9781107338326

Arendt, H. (1965). Eichmann in Jerusalem: A report on the banality of evil. New York: Viking Press.

Arendt, H. (1976). The origins of totalitarianism. New York: Harcourt Brace \& Co.

Blanchot, M. (1995) The writing of the disaster (A. Smock Trans.). Lincoln, NE: University of Nebraska Press.

Brooks, D. (2007). Obama, gospel, and verse. New York Times.

Crouter, R. (2010). Reinhold Niebuhr on politics, religion, and Christian faith. New York: Oxford University Press.

Douglas, M. (2002). Purity and danger: An analysis of concepts of pollution and taboo. London: Routledge,

Elshtain, J. B. (1995). Augustine and the limits of politics. Notre Dame, IN: University of Notre Dame Press.

Friedlander, S. (1993). Memory, history, and the extermination of the Jews of Europe. Bloomington, IN: Indiana University Press.

Gilkey, L. (2001). On Niebuhr: A theological study. Chicago: University of Chicago Press.

Goldhagen, D. J. (1996). Hitler's willing executioners: Ordinary Germans and the Holocaust. New York: Knopf.

Habermas, J. (2008). Between naturalism and religion: Philosophical essays. Malden, MA: Polity Press.

Havel, V. (1995). Forgetting that we are not God. First Things, 51, 4950 .

Hilberg, R. (1985). The destruction of the European Jews. New York: Holmes and Meier.

Hook, S. (1943). The new failure of nerve. Partisan Review, 12-13.

Horkheimer, M., \& Adorno, T. (2002). Dialectic of Enlightenment (E. Jephcott Trans). Stanford, CA: Stanford University Press.
Johnson, T. L. (2003). Christians and Jews: Starting over-Why the real dialogue has just begun. http://www.bc.edu/dam/files/research_sites/cjl/texts/cjrelations/resou rces/articles/johnson.htm

Kant, I. (1960). Religion within the limits of reason alone (T. H. Greene and H. Hudson Trans.). New York: Harper and Row. [orig. 1793]

Lang, B. (2000). Holocaust representation: Art within the limits of history and ethics. Baltimore, MD: Johns Hopkins University Press.

Lemert, C. (2011). Why Niebuhr matters. New Haven, CT: Yale University Press

Levi, P. (1996). Survival in Auschwitz (S. Woolf Trans.). New York: Simon \& Schuster.

Levi, P. (2001). The voice of memory: Primo Levi interviews 1961-1987. M. Belpoliti, \& R. Gordon (Eds.), New York: The New Press.

Rice, D. F. (2012). Reinhold Niebuhr and his circle of influence. New York: Cambridge University Press. http://dx.doi.org/10.1017/CBO9781139207737

Niebuhr, R. (1933). Germany must be told. The Christian Century, 1014-1015.

Niebuhr, R. (1944). The children of light and the children of darkness: A vindication of democracy and a critique of its traditional defense. Chicago, Il: University of Chicago Press.

Niebuhr, R. (1949) Faith and history: A comparison of Christian and modern views of history. New York: Charles Scribner's Sons.

Niebuhr, R. (1957). Jews after the war. In D. Robertson (Ed.), Love and justice: Selections from the shorter writings of Reinhold Niebuhr (pp. 132-142). Gloucester, MA: Peter Smith.

Niebuhr, R. (1965). Man's nature and his communities: Essays on the dynamics and enigmas of man's personal and social existence. New York: Charles Scribner's Sons.

Niebuhr, R. (1986). Augustine's political realism. In R. M. Brown (Ed.), The essential Reinhold Niebuhr (pp. 123-141). New Haven: Yale University Press.

Niebuhr, R. (1996). The nature and destiny of man: A Christian interpretation (2 vols.). Louisville, KY: John Knox Press.

Rice, D. (2012). Reinhold Niebuhr and his circle of influence. New York: Cambridge University Press. http://dx.doi.org/10.1017/CBO9781139207737

Rorty, R. (1989). Contingency, irony, and solidarity. Cambridge, UK: Cambridge University Press. http://dx.doi.org/10.1017/CBO9780511804397

Zank, M. (1998) Goldhagen in Germany: Historians' nightmare \& popular hero: An essay on the reception of Hitler's willing executioners in Germany. Religious Studies Review, 24, 231-245.

www.academia.edu/1552344/Goldhagen_in_Germany_Historians_N ightmare_and_Popular_Hero._An_Essay_on_the_Reception 